BLS 32, No 1 2006. DOI: http://dx.doi.org/10.3765/bls.v32i1.3471 (published by the Berkeley Linguistics Society and the Linguistic Society of America)

\title{
The Syntax of Floating Intensifiers in Polish and its Implications for the Determiner Phrase Hypothesis ${ }^{1}$
}

\author{
PAWEL RUTKOWSKI \\ Warsaw University/Yale University
}

\section{Introduction}

In this paper, I will attempt to show that the Polish word sam ('himself', an adjectival modifier) should be interpreted as a "floating intensifier" - a term I base on the parallel with so-called floating quantifiers (cf. Sportiche 1988). The surface syntactic position of the intensifier sam with respect to personal pronouns and nouns can serve as evidence as to the applicability of the Determiner Phrase hypothesis to Polish. I propose a generative analysis of why the adjective sam can appear both adnominally and adverbially, and how its position influences the scope of intensification.

\section{Noun/Pronoun Asymmetries in Polish: N-to-D Movement}

It has been proposed in the generative literature on nominal syntax (see, e.g., Willim 2000), that the lack of articles makes Abney's (1987) DP hypothesis inapplicable to languages such as Polish. Following the analysis of Serbian proposed by Progovac (1998), Rutkowski (2002b) argues that Polish nominal expressions must be analyzed as DPs at least in one case, namely when they include a personal pronoun. In this section, I will give a brief overview of this line of reasoning. The crucial observation made by Progovac (1998) and Rutkowski (2002b) is that nouns and personal pronouns occupy different surface syntactic slots in a number of nominal expressions in Serbian and Polish.

\footnotetext{
${ }^{1}$ For many useful comments on various aspects of this paper, I am indebted to Samuel D. Epstein, Jan Fellerer, Jadwiga Linde-Usiekniewicz, Giuseppe Longobardi, Paweł M. Nowak, Ljiljana Progovac, Marek Świdziński, Corey Yoquelet, and the audience at BLS 32. Earlier versions of this analysis were presented at the Annual Conference of the British Association for Slavonic and East European Studies (2004, Cambridge, UK), the 15th Colloquium on Generative Grammar (2005, Barcelona, Spain), the University of Michigan at Ann Arbor, Wayne State University, and Warsaw University. I would like to thank all these audiences for helpful feedback. The research reported here was partially supported by grants awarded by the Kosciuszko Foundation, the Foundation for Polish Science (FNP) and the Polish-American Fulbright Commission.
} 


\subsection{Pron Adj vs. Adj Noun}

Progovac (1998) shows that Serbian personal pronouns can never be pre-modified by adjectives. The only possibility of modification is to put the adjective in postposition:

(1a) I $\quad[n j u$ samu $]$ to nervira. and her herself that irritates 'That irritates even her.'

(1b) *I [samu nju $]$ to nervira. and herself her that irritates

On the other hand, regular nouns (including proper names) always follow their adjectival modifiers:

$$
\begin{array}{lll}
\text { I } & \text { [samu Mariju] } & \text { to nervira. } \\
\text { and herself Mary } & \text { that irritates }
\end{array}
$$

'That irritates even Mary.'

Progovac (1998) shows that such noun/pronoun asymmetries find a principled explanation if the DP hypothesis is assumed. Following the idea put forward by Postal (1969), many researchers analyze personal pronouns as occupying the D node. Progovac (1998) proposes a more complex derivation: according to her, pronouns originate in $\mathrm{N}$ (similarly to regular nouns) and are raised to $\mathrm{D}$ for referential reasons (cf. also Cardinaletti 1994). Therefore, they precede modifying adjectives in surface syntax (adjectives are specifiers in a functional projection located in the region in between DP and NP).

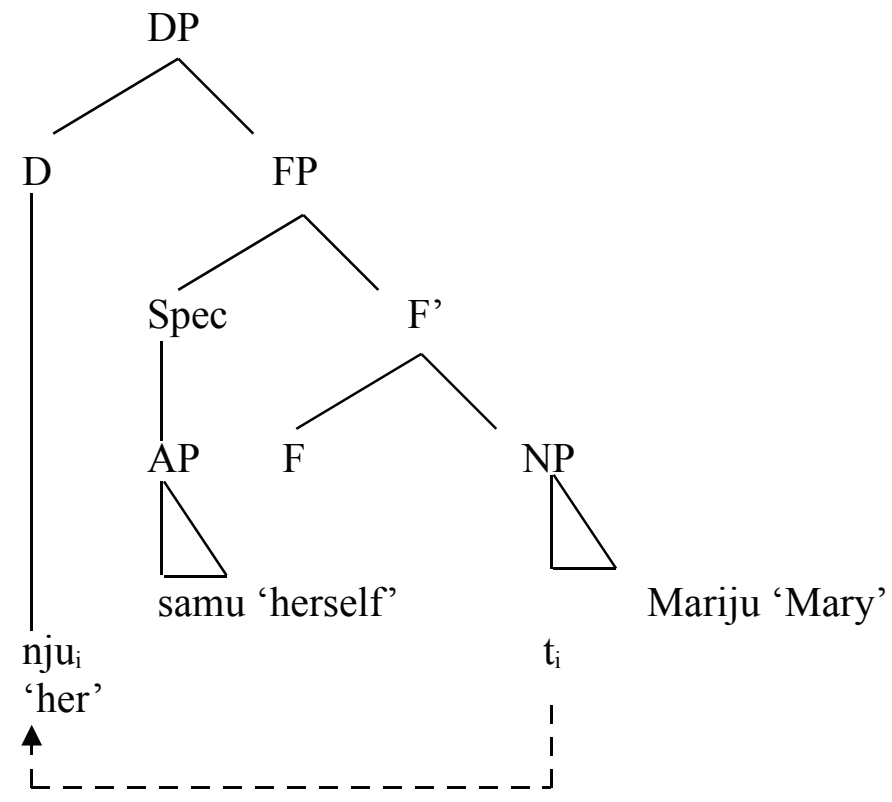




\section{The Syntax of Floating Intensifiers in Polish}

If adjectives are taken to reside in the specifier of a functional projection above the noun, the personal pronoun arguably moves to the head of that projection first (so that the features of the adjectives can be checked - cf., e.g., Cinque 1994) and then to the D node. Therefore, the diagram in (3) (as well as other diagrams in the present paper) is a simplified illustration of the N-to-D movement of personal pronouns.

Interestingly, Polish exhibits a pattern of noun/pronoun asymmetries which is exactly parallel to the Serbian one shown in (1-2):

(4a) $\left[\begin{array}{ll}\text { On } & \text { sam }\end{array}\right] \quad$ nas irytuje.

he himselfus irritates

'He himself irritates us.'

$\begin{array}{lll}*[\text { Sam } & \text { on] } & \text { nas irytuje. } \\ \text { himselfhe } & \text { us } & \text { irritates }\end{array}$

[Sam dyrektor] nas irytuje.
himselfdirector us irritates
'The director himself irritates us.'

Rutkowski (2002b) adopts the analysis proposed by Progovac (1998) and extends it by showing that similar cases of noun/pronoun asymmetries are not limited to structures with adjectives. As will be discussed below, various kinds of Polish modifiers must follow personal pronouns, although they normally precede nouns. Such DP-internal word order facts support the view that Polish must be a DP-type language, although it lacks overt articles (Veselovská (2003) and Franks and Pereltsvaig (2004) present similar accounts of Czech and Russian, respectively). It should be noted that the N-to-D analysis of the syntax of personal pronouns does not imply that all nominal expressions in languages such as Polish must be considered DPs. Following Longobardi (1994), I assume that the DP layer is necessary for argumenthood. However, if a nominal expression is not an argument, no functional structure needs to be projected above the NP level. Longobardi (2006) provides an interesting argument for the lack of the DP layer in certain non-argumental positions. He points out that personal pronouns surface post-adjectivally in exclamations such as the following:

(6) Poveri noi!

poor we

'Poor us!'

Longobardi (2006) interprets the whole exclamation as a bare NP. This analysis is confirmed by the fact that no determiners can be used in such constructions: 
(7a) Povero cane!

poor dog

'Poor dog!'

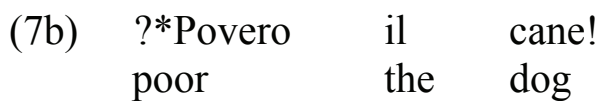

Longobardi (2006) suggests that example (6) receives a straightforward explanation if the personal pronoun is analyzed as occupying $\mathrm{N}$. Thus, there seems to be no N-to-D raising in this case. Interestingly, certain exclamations in Polish do not seem to involve the raising of pronouns either:

(8a) Cały ty!

whole you

'It's so typical of you!'

(8b) *Ty cały!

you whole

(9) Cały Cezary!

whole Cezary

'It's so typical of Cezary!'

The word caty 'whole' is an adjective that agrees with the (pro)noun. The above examples seem to support the idea that non-arguments are not necessarily DPs in Polish. When they are bare NPs, personal pronouns must surface in N, so their overt syntactic position is not different from the one occupied by regular nouns $\operatorname{cf}(9)$.

\subsection{Pron $\mathbf{Q}$ vs. $Q$ Noun}

The assumption that the surface position of personal pronouns is in D finds confirmation in the following data:

(10a) [My wszyscy $]$ cię irytujemy.

you irritate

'All of us irritate you.'

(10b) *[Wszyscy my] cię irytujemy. all we you irritate

'All of us irritate you.'

(11) [Wszyscy lingwiści] cię irytują. all linguists you irritate

'All linguists irritate you.' 


\section{The Syntax of Floating Intensifiers in Polish}

The quantifier wszyscy 'all' follows personal pronouns in Polish, but precedes regular nouns. Independently from its position, wszyscy always exhibit agreement with the quantified noun/pronoun, therefore, it seems justified to analyze it as located in the specifier of a functional head above the NP (case, gender, and number agreement being an instance of spec-head relation, cf. Rutkowski 2002a). The quantified element is always base generated in N, however, if it is a personal pronoun, its strong referentiality makes it move to D. The following figure illustrates the internal structure of Polish expressions with the general quantifier wszyscy (cf. Rutkowski 2002b):

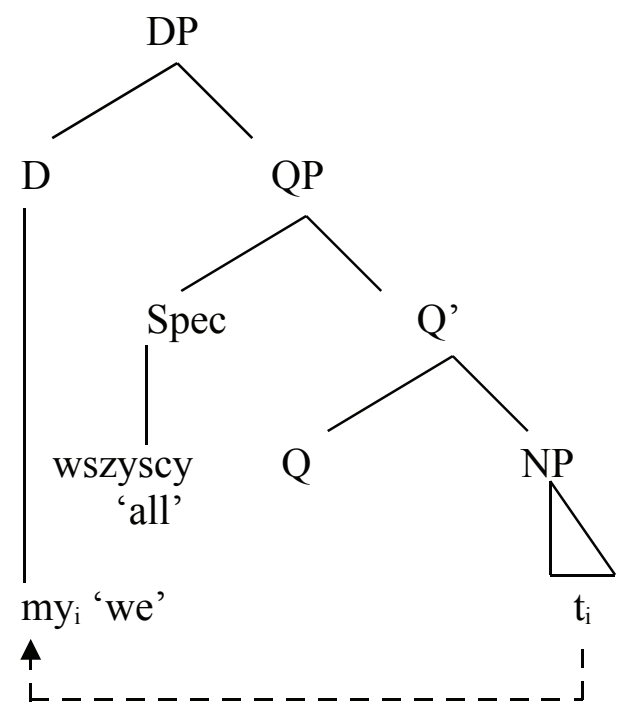

The syntactic configuration shown in (12) supports the model outlined in Section 2.1. Since personal pronouns are strongly referential, they must be raised to D (Nto-Q is most likely the first step of this movement, however this issue does not influence the analysis I argue for). Therefore, they precede quantifiers in surface syntax.

\subsection{Pron Num vs. Num Noun}

The syntax of cardinal numerals is another instance of noun/pronoun asymmetries in Polish. Similarly to adjectives and quantifiers, numerals normally precede nouns, but follow pronouns:

[Nas pięciu] cię
we:GEN frytuje.
'Five of us irritate you.'

$\begin{array}{llll}* \text { [Pięciu } & \text { nas] } & \text { cię } & \text { irytuje. } \\ \text { five } & \text { we:GEN } & \text { you } & \text { irritate }\end{array}$


(14) [Pięciu lingwistów] cię irytuje.

five linguists:GEN you irritate

'Five linguists irritate you.'

The above structure is even more interesting than those presented in Sections 2.1 and 2.2 because it provides a very clear argument for the claim that personal pronouns are base generated in N. It should be noted that, as shown in (14), numerals such as pięć 'five' assign genitive to the following noun. Since the pronoun in (13a) is also marked genitive, it must be analyzed as merged inside the NP and then raised to D. The derivation of (13a) is illustrated below:

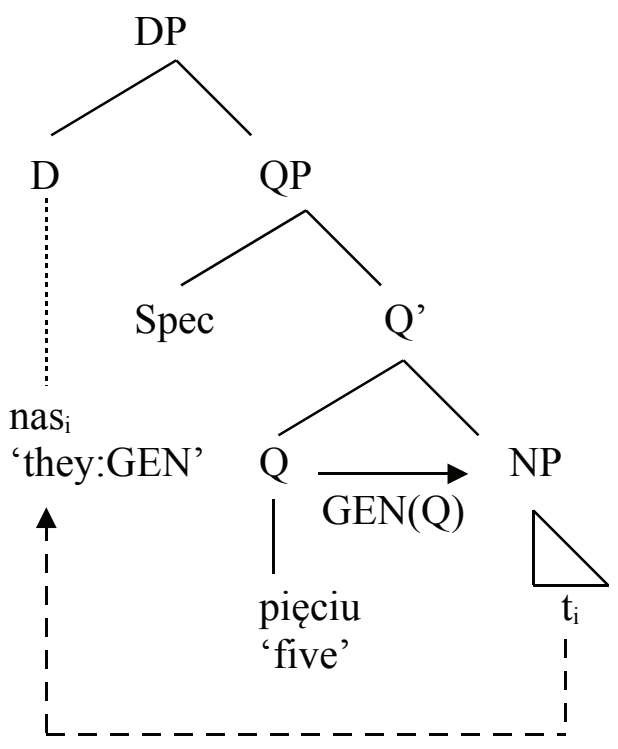

If the pronoun were base generated in $\mathrm{D}$, the genitive assignment would not be possible $(\mathrm{GEN}(\mathrm{Q})$ is assigned locally, i.e. within the QP; see Rutkowski 2002a, for a detailed discussion of the syntax of Polish QPs).

\section{The Phenomenon of sam-float}

In Section 2, I have shown that Polish personal pronouns differ from nouns in terms of their surface syntactic position. The fact that there are many expressions in which modifiers such as adjectives, numerals or quantifiers follow pronouns suggests that the latter are raised to D. This, in turn, is a strong argument for the DP analysis of Polish nominals. However, the N-to-D model presented in the previous section seems to be questioned by examples such as the following:

$$
\begin{aligned}
& \text { Dyrektor sam nas irytuje. } \\
& \text { director himselfus irritates } \\
& \text { 'The director irritates us himself.' }
\end{aligned}
$$




\section{The Syntax of Floating Intensifiers in Polish}

In (16), the element sam is apparently admitted to the right of the head noun. This should not be allowed because Polish nouns, unlike personal pronouns, are not raised to $\mathrm{D}$ in overt syntax. If it was really the case that adjectives may surface post-nominally, the noun/pronoun asymmetries described in the first part of this paper could not be treated as clear evidence for the DP model. However, in what follows I will argue that the element sam in (16) is not part of the subject DP in surface syntax. This analysis finds support in the fact that interrupting/ parenthetical expressions cannot separate the post-nominal sam from the verbal complex. As illustrated in (17d), if sam surfaces post-nominally, its position seems adverbial. On the other hand, example (17c) shows that dyrektor sam 'director himself' is not a syntactic constituent (as opposed to sam dyrektor 'himself director' in (17a) or on sam 'he himself' in (17b)). I conclude that the post-nominal sam surfaces outside of the subject DP in examples such as (17d). Instead, it belongs to the verbal complex.

(17a) Sam dyrektor, jak wiemy - człowiek inteligentny, czytał mój artykuł. himself director as all we know man very intelligent read my article 'The director himself, as we know - an intelligent person, read my article.'

(17b) On sam, jak wiemy - człowiek inteligentny, czytał mój artykuł. he himself as all we know man very intelligent read my article 'He himself, as we all know - a very intelligent person, read my article.'

(17c) *Dyrektor sam, jak wiemy - człowiek inteligentny, czytał mój artykuł. director himself as all we know man very intelligent read my article

(17d) Dyrektor, jak wiemy - człowiek inteligentny, sam czytał mój artykuł. director himself as all we know man very intelligent read my article 'The director, as we know - an intelligent person, read my article himself.'

König and Siemund (1999) call elements such as selbst in German, x-self in English or x-même in French intensifiers. They point out that, cross-linguistically, intensifiers often have at least two uses: an adnominal one and an adverbial one (see (18) and (19), respectively):

(18) I would like to talk to the director himself.

(19) The director wrote that speech himself.

Many languages further differentiate between two distinct adverbial uses: an exclusive one (with the interpretation 'alone'/"without help'), as illustrated in (20), and an inclusive one ('too'), as illustrated in (21).

The director repaired that car himself. 
(21) I had a car like that myself.

It seems that the three uses of intensifiers distinguished by König and Siemund (1999) are also available in Polish:

[Sam dyrektor] może przyjąć nas jutro. [adnominal] himself director can receive us tomorrow 'The director himself can receive us tomorrow.'

(23) Dyrektor [sam nareperował ten samochód]. [adverbial, exclusive] director himself repaired this car 'The director repaired that car himself.'

(24) Dyrektor [sam miał taki samochód]. [adverbial, inclusive] director himself had such car 'The director had a car like that himself.'

If we adopt König and Siemund's (1999) analysis saying that the uses of sam shown in (23-24) are adverbial (this is illustrated above with appropriate bracketing), it becomes clear why they do not exhibit the pattern of noun/pronoun word order asymmetries exemplified in (4-5). It is only in the adnominal use shown in (22) that the element sam is actually part of the DP.

Surprisingly, the adverbial intensifier sam in structures such as (23-24) manifests adjectival behavior in terms of case, gender and number agreement with the head noun:

Mój ojciec sam miał taki samochód.

my father himselfhad such car

'My father had a car like that himself.'

(26) Moja matka sama miała taki samochód.

my motherherself had such car

'My mother had a car like that herself.' 


\section{The Syntax of Floating Intensifiers in Polish}

Moreover, the element sam has to agree with the subject independently from its surface position inside the verbal complex:

(27a) [Moja żona] [sama będzie jutro reperować ten samochód]. my wife herself will tomorrow repair this car [Moja żona] [będziesama jutro reperować ten samochód]. my wife will herself tomorrow repair this car

(27c) [Moja żona] [będziejutro sama reperować ten samochód]. my wife will tomorrow herself repair this car 'Tomorrow, my wife will repair that car herself.'

The pattern presented above seems intriguingly similar to the one exhibited in many languages by so-called floating quantifiers (cf. Puskas 2002, Bobaljik 2003):

\begin{tabular}{|c|c|c|c|c|c|c|c|}
\hline (28a) & $\frac{\text { Tous }}{\text { All }}$ & les & & $\begin{array}{l}\text { ont } \\
\text { have }\end{array}$ & $\begin{array}{l}\text { réalisé } \\
\text { realized }\end{array}$ & un & $\begin{array}{l}\text { projet. } \\
\text { proiect }\end{array}$ \\
\hline (28b) & $\begin{array}{l}\text { Les } \\
\text { the }\end{array}$ & $\begin{array}{l}\text { architectes } \\
\text { architects }\end{array}$ & $\begin{array}{l}\text { ont } \\
\text { have }\end{array}$ & $\frac{\text { tous }}{\text { all }}$ & $\begin{array}{l}\text { réalisé } \\
\text { realized }\end{array}$ & un & $\begin{array}{l}\text { projet. } \\
\text { project }\end{array}$ \\
\hline & $\begin{array}{l}\text { Les } \\
\text { the }\end{array}$ & $\begin{array}{l}\text { architectes } \\
\text { architects }\end{array}$ & $\begin{array}{l}\text { ont } \\
\text { have }\end{array}$ & $\begin{array}{l}\text { réalisé } \\
\text { realizec }\end{array}$ & $\frac{\text { tous }}{\text { all }}$ & $\begin{array}{l}\text { un } \\
\text { a }\end{array}$ & $\begin{array}{l}\text { projet. } \\
\text { project. }\end{array}$ \\
\hline
\end{tabular}
'All the architects realized a project.'

Sportiche (1988) accounts for the data in (28) by arguing that quantifiers such as tous 'all' are always base generated in the DP-initial position. He further assumes that the structure in which the sentential subject occupies the specifier of IP is derived from the underlying structure in which the subject is VP-internal. As the subject moves up from its base position (in a step-wise, head-to-head fashion), it leaves traces. Sportiche (1988) interprets the phenomenon of Q-float as the stranding of the quantifier in a position adjacent to the trace of the subject DP. This is illustrated below: the phrase-marker in (29) corresponds to examples (30ad), the label $F P$ standing for any verbal functional projection: 


\section{Paweł Rutkowski}

(29)
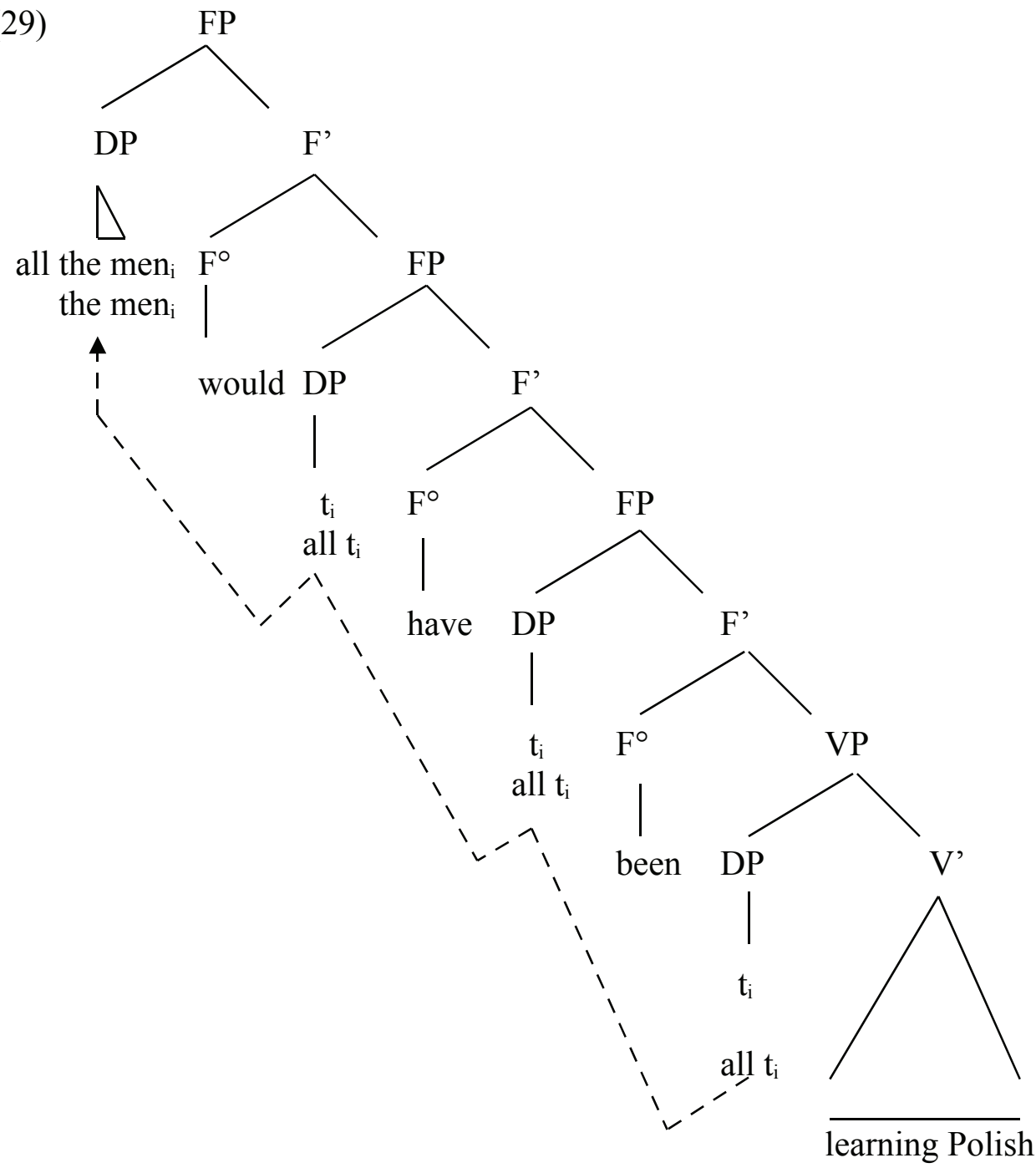

(30a) All the men would have been learning Polish.

(30b) The men would all have been learning Polish.

(30c) The men would have all been learning Polish.

(30d) The men would have been all learning Polish.

I argue that Sportiche's (1988) analysis could also be used to account for the phenomenon of sam-float shown in (27). The intensifier sam is always base generated as a modifier of the subject noun (hence the adjectival agreement). Subsequently, the subject moves from its base (VP-internal) position to Spec-IP. Thus, the variations of surface word order shown in (31) are all derived from structure (32): 


\section{The Syntax of Floating Intensifiers in Polish}

(31a) Sam dyrektor będzie mógł zjeść banana. himselfdirector will be-ableeat banana 'The director himself will be able to eat a banana.'

Dyrektor będzie sam mógł zjeść banana.
director

'The director will himself be able to eat a banana.'

(31c) Dyrektor będzie mógł sam zjeść banana. directot will be-ablehimselfeat banana

'The director will be able to eat a banana himself.'
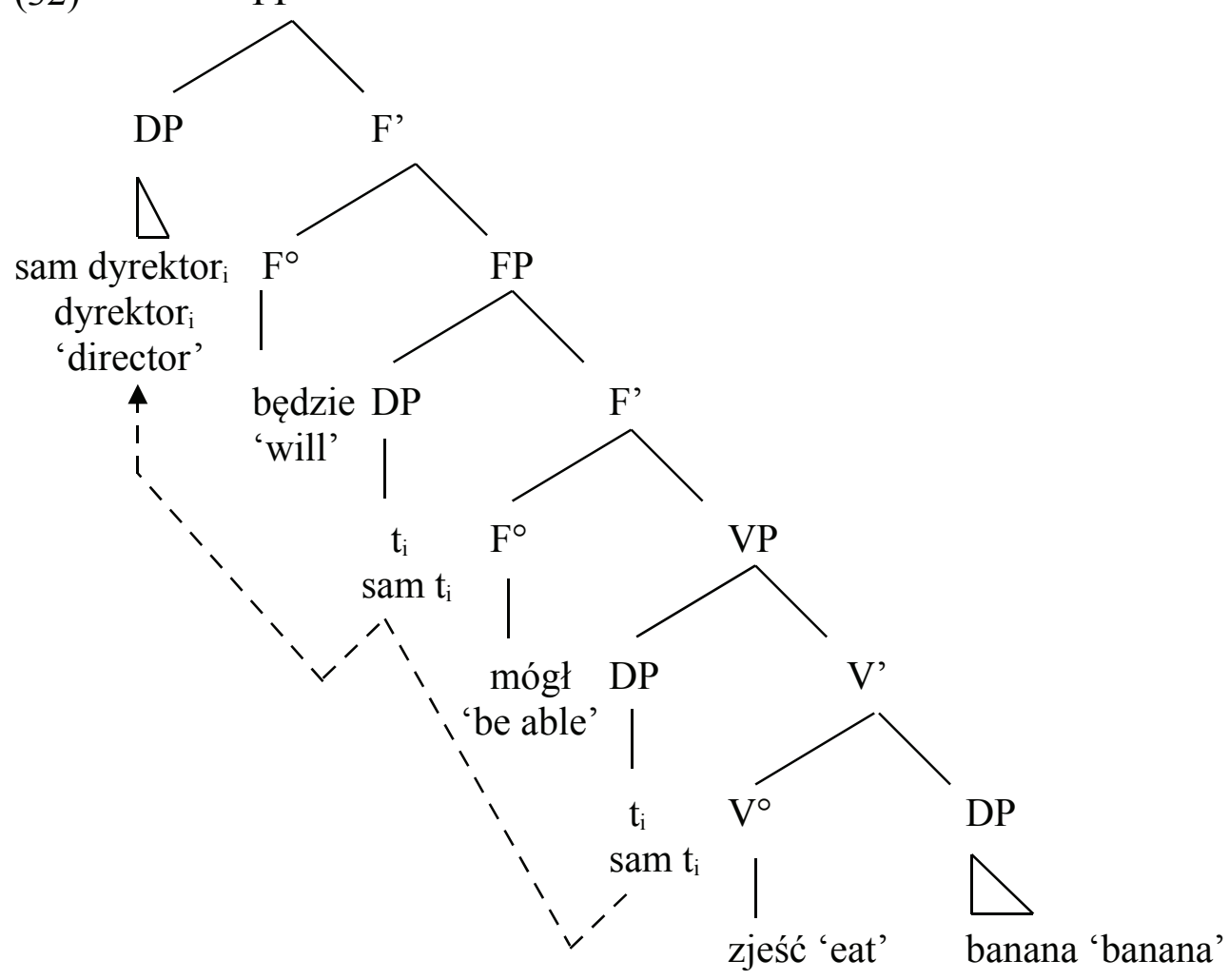

If the intensifier sam is stranded within the VP, its interpretation must be 'exclusive'; if it is stranded above the VP it becomes a marker of 'inclusiveness'; if no stranding occurs, the only available interpretation is the adnominal (focalizing) one.

It should be noted that the stranding analysis outlined above is supported by the fact that neither the floating quantifier in (30) nor the floating intensifier in (31) can appear more than once in one sentence:

*All the men would all have been learning Polish. 
Paweł Rutkowski

(33)

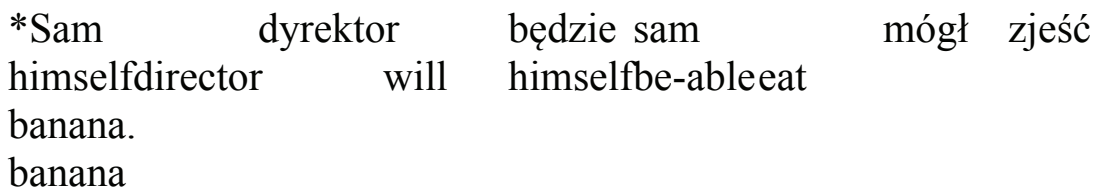

Example (33) clearly indicates that the adnominal sam and the adverbial sam cannot be merged independently.

\section{Conclusion}

I conclude that the DP analysis of Polish nominals (as presented in Section 2) is not disproved by the fact that the intensifier sam may surface postnominally. Neither does it seem necessary to assume that there are multiple lexical entries for the intensifier sam (an adnominal one and an adverbial one). Sam is always base generated as a DP-internal adnominal modifier, but it does not have to end up in the surface position of the subject it belongs to. When the intensifier is stranded, its interpretation changes to what König and Siemund (1999) call 'inclusive' or 'exclusive'. It should also be added that the phenomenon of sam-float is possible only because floated intensifiers do not yield the same interpretation as nonfloated ones (otherwise, floating would be redundant).

\section{References}

Abney, Steven P. 1987. The English Noun Phrase in its Sentential Aspect. Ph.D. diss., MIT.

Bobaljik, Jonathan David. 2003. Floating Quantifiers: Handle with Care. In Lisa Cheng and Rint Sybesma, eds., The Second Glot International State-of-theArticle Book. The Latest in Linguistics, 107-148. Berlin, New York: Mouton de Gruyter.

Cardinaletti, Anna. 1994. On the Internal Structure of Pronominal DPs. The Linguistic Review 11:195-219.

Cinque, Guglielmo. 1994. On the Evidence for Partial N Movement in the Romance DP. In Guglielmo Cinque, Jan Koster, Jean-Yves Pollock, Luigi Rizzi, and Raffaella Zanuttini, eds., Paths towards Universal Grammar: Studies in Honor of Richard S. Kayne, 85-110. Washington, D.C.: Georgetown University Press.

Franks, Steven. 1995. Parameters of Slavic Morphosyntax. New York, Oxford: Oxford University Press.

Franks, Steven, and Asya Pereltsvaig. 2004. Functional Categories in the Nominal Domain. In Olga Arnaudova, Wayles Browne, Maria Luisa Rivero, and Danijela Stojanović, eds., Formal Approaches to Slavic Linguistics: the Ottawa Meeting 2003, 109-128. Ann Arbor: Michigan Slavic Publications.

König, Ekkehard, and Peter Siemund. 1999. Intensifiers as Targets and Sources of Semantic Change. In Klaus von Heusinger and Regine Eckardt, eds., Meaning 


\section{The Syntax of Floating Intensifiers in Polish}

Change - Meaning Variation, 97-109. Konstanz: Fachgruppe Sprachwissenschaft, Universität Konstanz.

Longobardi, Giuseppe. 1994. Reference and Proper Names: A Theory of NMovement in Syntax and Logical Form. Linguistic Inquiry 25:609-665.

Longobardi, Giuseppe. 2006. Reference to Individuals, Person, and the Variety of Mapping Parameters. Ms., Università di Trieste.

Postal, Paul M. 1969. On So-called 'Pronouns' in English. In: David A. Reibel and Sanford A. Schane, eds., Modern Studies in English: Readings in Transformational Grammar, 201-224. Englewood Cliffs, NJ: Prentice-Hall.

Progovac, Ljiljana. 1998. Determiner Phrase in a Language without Determiners. Journal of Linguistics 34:165-179.

Puskas, Genoveva. 2002. Floating Quantifiers: What They Can Tell Us about the Syntax and Semantics of Quantifiers. Generative Grammar in Geneva 3:105128.

Rutkowski, Paweł. 2002a. The Syntax of Quantifier Phrases and the Inherent vs. Structural Case Distinction. Linguistic Research/Recherches linguistiques 7(1):43-74.

Rutkowski, Paweł. 2002b. Noun/Pronoun Asymmetries: Evidence in Support of the DP Hypothesis in Polish. Jezikoslovlje 3(1-2):159-170.

Sportiche, Dominique. 1988. A Theory of Floating Quantifiers and Its Corollaries for Constituent Structure. Linguistic Inquiry 19:425-449.

Veselovská, Ludmila. 2003. A Note about Nothing. In Peter Kosta, Joanna Błaszczak, Jens Frasek, Ljudmila Geist, and Marzena Żygis, eds., Investigations into Formal Slavic Linguistics: Contributions of the Fourth European Conference on Formal Description of Slavic Languages - FDSL IV, Vol. 2, 745-758. Frankfurt am Main: Peter Lang.

Willim, Ewa. 2000. On the Grammar of Polish Nominals. In Roger Martin, David Michaels, and Juan Uriagereka, eds., Step by Step: Essays on Minimalism in Honor of Howard Lasnik, 319-346. Cambridge, MA: MIT Press.

Department of General Linguistics and Baltic Studies

Katedra Językoznawstwa Ogólnego i Bałtystyki

Wydział Polonistyki, Uniwersytet Warszawski

ul. Krakowskie Przedmieście 26/28

00-927 Warszawa

Poland

p.rutkowski@uw.edu.pl 